\title{
LA-UR-- $98-508$
}

Title:

Analysis of Polyurethane Elastomer Using Thermal 2D FT-1R

CONF-980314--

D.K. Graff

D.A. Wsobleski

A.L. Marsh

E.M. Kober

M.E. Smith

J.R. Schoonover

RECEIVEC

JUL 011998

OSTI

Submitted to:

PSME

DISTRIBUTION OF THIS DOCUMENT 15 UAMIMTED

\section{Los Alamos}

NATIONAL LABORATORY

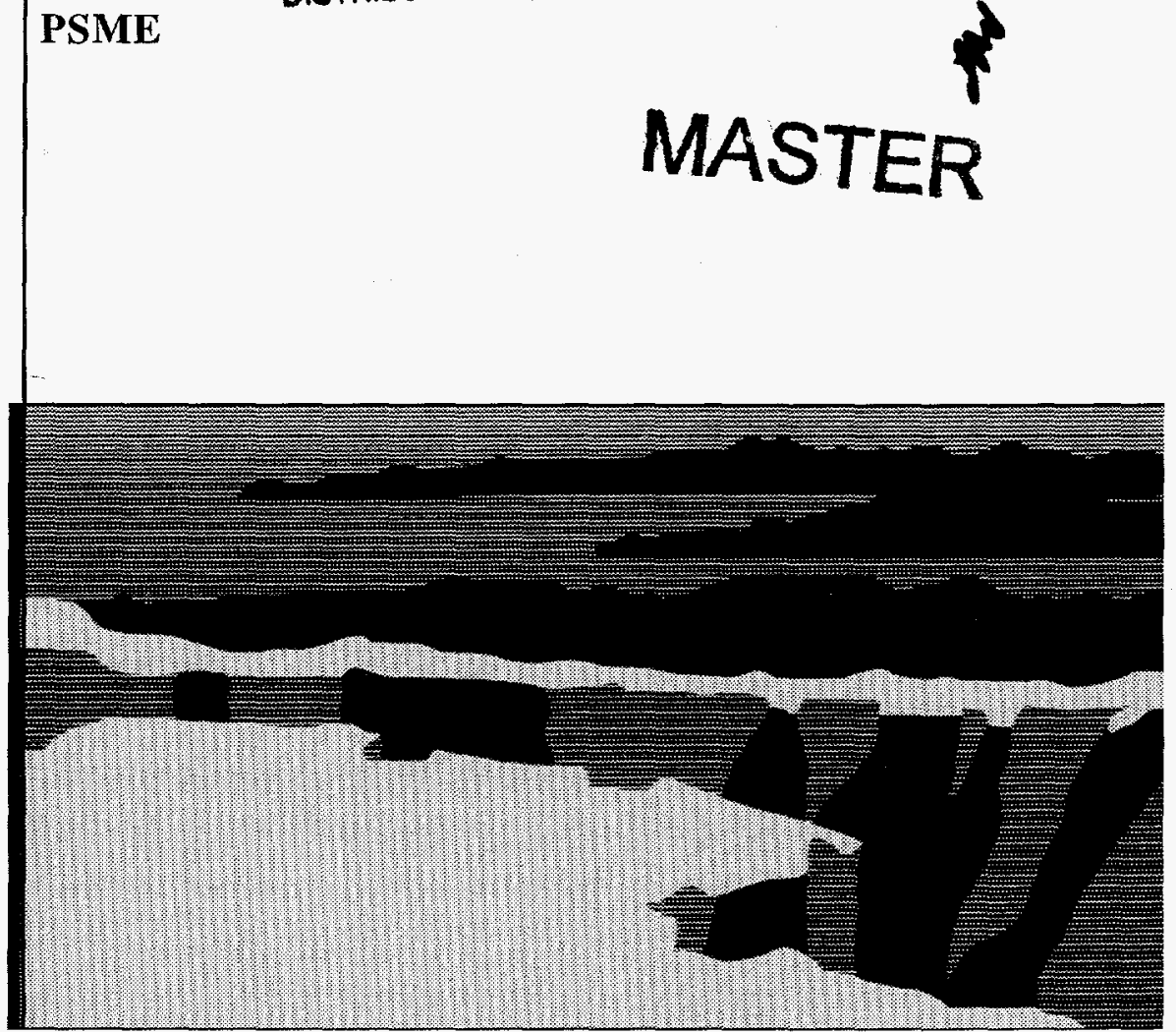

Los Alamos National Laboratory, an affirmative action/equal opportunity employer, is operated by the University of California for the U.S. Department of Energy under contract W-7405-ENG-36. By acceptance of this article, the publisher recognizes that the U.S. Government retains a nonexclusive, royalty-free license to publish or reproduce the published form of this contribution, or to aliow others to do so, for U.S. Government purposes. The Los Alamos National Laboratory requests that the publisher identify this article as work performed under the auspices of the U.S. Department of Energy. 


\section{DISCLAMMER}

This report was prepared as an account of work sponsored by an agency of the United States Government. Neither the United States Government nor any agency thereof, nor any of their employees, makes any warranty, express or implied, or assumes any legal liability or responsibility for the accuracy, completeness, or usefulness of any information, apparatus, product, or process disclosed, or represents that its use would not infringe privately owned rights. Reference herein to any specific commercial product, process, or service by trade name, trademark, manufacturer, or otherwise does not necessarily constitute or imply its endorsement, recommendation, or favoring by the United States Government or any agency thereof. The views and opinions of authors expressed herein do not necessarily state or reflect those of the United States Government or any agency thereof. 


\section{DISCLAIMER}

Portions of this document may be illegible electronic image products. Images are produced from the best available original document. 
Analysis of a Polyurethane Elastomer Using Thermal 2D FT-IR, D.K. Graff, D.A. Wrobleski, A.L. Marsh, E.M. Kober, M.E. Smith, J.R. Schoonover, Los Alamos National Laboratory, Los Alamos NM, 87545.

Introduction: Polyurethane-polyester elastomers contain hard and soft domains which give these materials unique structural and elastic properties and lead to their use in various applications. It is desirable to characterize the molecular-level interactions giving rise to the two domains and to use this information to monitor chemical changes which take place in the polymer as a function of exposure to agents known to effect structural changes. Infrared spectroscopy has been used to study polymeric structures, including polyurethane elastomers, ${ }^{1}$ as the vibrational absorption bands characteristic of different functional groups are sensitive to changes in their chemical environment. One difficulty in the application of infrared spectroscopy to complex chemical systems has been the ambiguitiy of interpretation due to the limitations of different deconvolution techniques. Noda's development of a $2 \mathrm{D}$ correlation method ${ }^{2}$ provides a means by which convoluted spectral information, such as that arising from the two domains of estane, can be resolved as a function of some perturbation. We present here a thermal 2D FT-IR study of estane.

Experimental: Estane ${ }_{\circledast}$, obtained from B.F.Goodrich, has the form $\left[\left(\mathrm{CH}_{2}\right)_{4} \mathrm{OOCNH}\left(\mathrm{C}_{6} \mathrm{H}_{4}\right) \mathrm{CH}_{2}\left(\mathrm{C}_{6} \mathrm{H}_{4}\right) \mathrm{NHCOO}_{\mathrm{m}}\left[\left(\mathrm{CH}_{2}\right)_{4} \mathrm{OOC}\left(\mathrm{CH}_{2}\right)_{4} \mathrm{COO}\right]_{\mathrm{n}}\right.$. Samples were prepared by casting a dilute MEK solution of the polymer onto $13 \mathrm{~mm} \times 2 \mathrm{~mm} \mathrm{BaF}_{2}$ windows. Sample thickness yielded a maximum absorbance under 1.6 absorbance units.

Samples were mounted between two $\mathrm{BaF}_{2}$ windows in an aluminum block cell containing a cartridge heater and connected to a temperature controller. The temperature $\left( \pm 0.1^{\circ} \mathrm{C}\right)$ was monitored through a Type $\mathrm{K}$ thermocouple placed next to the sample in the temperature cell. Sixteen spectra were collected with a Nicolet 20SXB FTIR spectrometer at approximately equal temperature intervals from 35 to $80^{\circ} \mathrm{C}$. 128 scans were measured with a resolution of $4 \mathrm{~cm}^{-1} .2 \mathrm{D}$ plots were calculated using the MathCad (Mathsoft) software package.

Results: The absorption spectra are shown as a function of temperature in Figure 1. Synchronous (real) and asynchronous (imaginary) components of the cross-correlation analysis of this data, from 1500 to $1800 \mathrm{~cm}^{-1}$, are shown in Figures 2 and 3, respectively. 


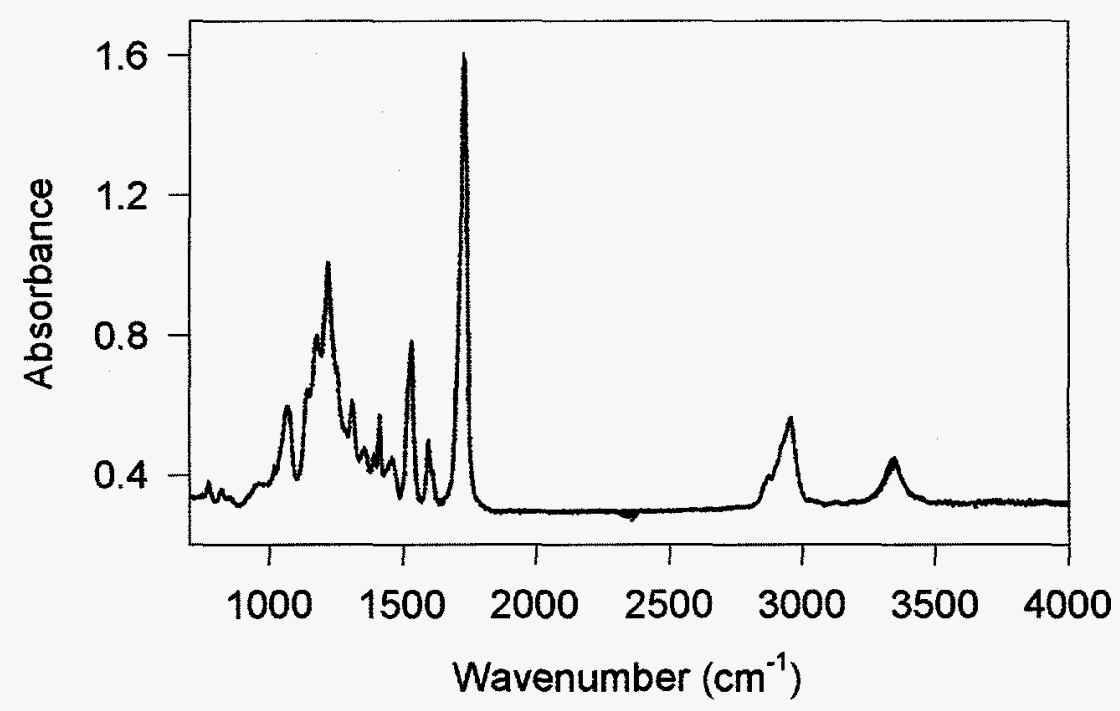

Figure 1: Sixteen infrared absorption spectra of estane at temperatures ranging from 35 to $80^{\circ} \mathrm{C}$. Each spectrum is an average of 128 , resolution $4 \mathrm{~cm}^{-1}$, referenced to air and baseline corrected for the presence of atmospheric water.

Discussion: The spectra in Figure 1 reflect the molecular-level changes which give rise to a hard-segment ordering transition in the $60-80^{\circ} \mathrm{C}$ temperature range. The $2 \mathrm{D}$ plots of the $1500-1800 \mathrm{~cm}^{-1}$ region, Figures 2 and 3 , illustrate the usefulness of the analysis technique. Intensity arises in the 2D plots for a pair of vibrations whose responses to the perturbation are correlated in specific ways. For example, a positive feature in the synchronous plot occurs for two bands which are simultaneously changing and in the same direction (i.e. both increasing); a negative feature indicates bands which are simultaneously changing

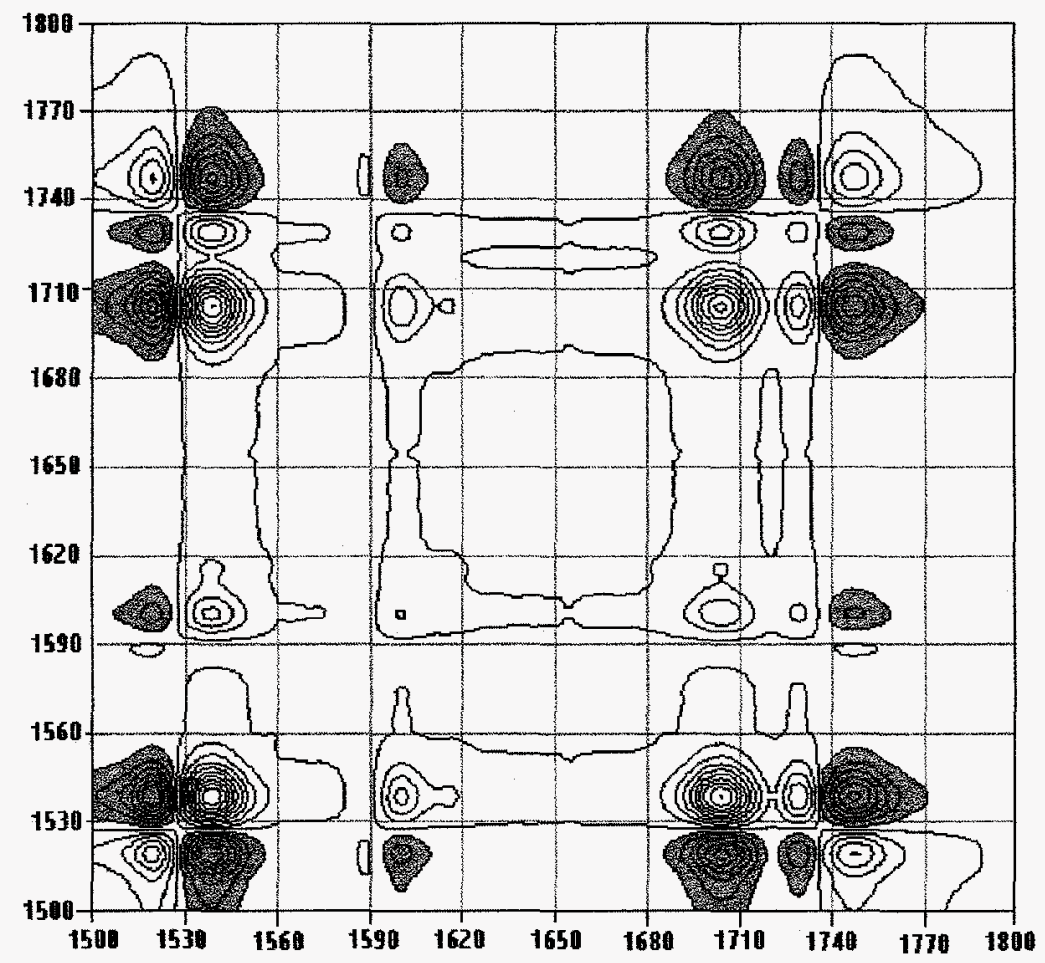

Figure 2: Synchronous correlation plot of estane, 1500 to $1800 \mathrm{~cm}^{-1}$; shading indicates negative contours. 


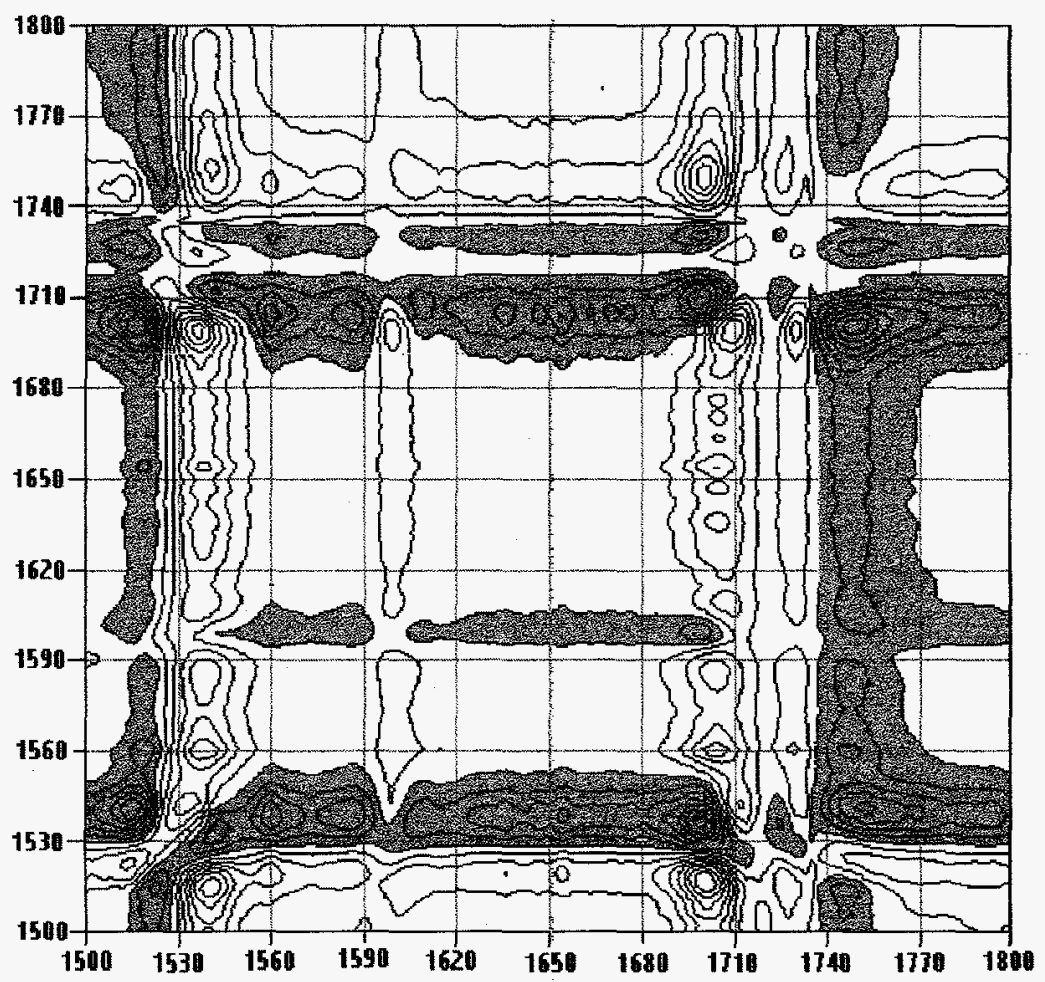

Figure 3: Asynchronous correlation plot of estane, 1500 to $1800 \mathrm{~cm}^{-1}$; shading indicates negative contours.

but in an opposite direction (one increasing, one decreasing). The 1500 to $1800 \mathrm{~cm}^{-1}$ region contains three spectral features: the $\mathrm{v}(\mathrm{C}=\mathrm{O})$ at 1720 $\mathrm{cm}^{-1}$ (both hard and soft domains), the $v(\mathrm{C}=\mathrm{C})$ at $1600 \mathrm{~cm}^{-1}$, and the $v(\mathrm{C}-$ N) plus $\delta(\mathrm{N}-\mathrm{H})$ at $1535 \mathrm{~cm}^{-1}$. Changes are seen in $\mathrm{N}-\mathrm{H}$ hydrogen bonding as the temperature is raised (data not shown); we expect to see these changes in the $v(\mathrm{C}=\mathrm{O})$ region as well, and also expect to resolve the $\mathrm{C}=\mathrm{O}$ contributions from the hard and soft domains. Note that in the $v(C=O)$ region of the synchronous plot, the band has clearly been resolved into three frequency components, while the $v(\mathrm{C}-\mathrm{N})$ plus $\delta(\mathrm{N}-\mathrm{H})$ region of the synchronous plot has given rise to two distinct components; the asynchronous plots of these regions show further complexity. Correlations of these modes with that of the phenyl $v(C=C)$ mode is also clearly observed. By assessing the cross correlations through the entire frequency range, it is possible to assign spectral components and to interpret their behaviors with confidence.

\section{References:}

1(a) Srichatrapimuk, V. W.; Cooper, S. L., J. Macromol. Sci., Phys., B15, 267, 1978. (b) Christenson, C. P.; Harthcock, M. A.; Meadows, M. D.; Spell, H. L.; Howard, W. L.; Creswick, M. W.; Guerra, R. E.; Turner, R. B., J. Polym. Sci., Polym. Phys. Ed., 24, $1401,1986$.

2(a) Noda, I. J. Am. Chem. Soc., 111, 8116, 1989. (b) Noda, I. Applied Spectrosc., 44, $550,1990$. 